\section{Universitetet i Oslo}

www.med.uio.no/disputaser/

Vuk Palibrk, ph.d. Molecular and pathophysiological functions of promyelocytic leukemia protein. Utgår fra Institutt for klinisk medisin. Disputas 20.3. 2015.

Bedømmelseskomité: Rosa Bernardi, Division of Molecular Oncology, Leukemia Unit, San Raffaele Scientific Institute, Milano, Italia, Hrvoje Miletic, Institutt for biomedisin, Universitetet i Bergen, og Philippe Collas, Seksjon for biomedisin, Institutt for medisinske basalfag, Universitetet i Oslo. Veileder: Stig Ove Bøe.

Marianne Westberg, ph.d. On prosthetic joint infections - treatment and prevention. Utgår fra Institutt for klinisk medisin.

Disputas 26.3. 2015.

Bedømmelseskomité: Anna Stefánsdóttir, Skånes universitetssykehus, Lund, Sverige, Jan-Erik Berdal, Akershus universitetssykehus, Lørenskog, og Peter Gaustad, Institutt for klinisk medisin, Universitetet i Oslo.

Veiledere: Finnur Snorrason, Bjarne Grøgaard og Lars Nordsletten.
MELDTE DØDSFALL

Halvor Brandt 11.3. 1944-5.3. 2015

Jan-Åke Roland Johannesson 16.2. 1946-5.3. 2015

Per Gunnar Eng 8.12. 1937-2.3. 2015

John Bjørn Nilsen 30.5. 1942-21.2. 2015

Arne Serck-Hanssen 28.2. 1925-27.11. 2014

\title{
ERC-støtte til norsk kreftforsker
}

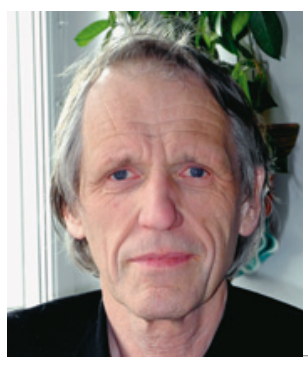

Eliv Lund. Foto: Elisabeth Øvreberg, Universitetet i Tromsø

Eiliv Lund (f. 1947), kreftforsker og professor ved Institutt for samfunnsmedisin ved Universitetet i Tromsø, har som første nordmann fått det europeiske forskningsrådets (ERC) kommersialiseringsstøtte - «proof of consept». Støtten gis til dyktige søkere med usedvanlig gode prosjekter eller med solid bakgrunn. Lund var blant 59 fremragende forskere som i februar 2015 ble innvilget «proof of concept».

Lund leder prosjektet Kvinner og kreft, som inkluderer 172000 norske deltakere og en biobank med 50000 blodprøver og nedfryst vev fra brystkreftsvulster. I forbindelse med dette prosjektet har han utviklet en blodprøvemetode som kan brukes til å påvise brystkreft. Metoden er enkel og rimelig. Den kan brukes sammen med andre diagnosemetoder og dermed også bidra til å redusere antall feildiagnoser, ifølge Forskningsrådet (1). Siden testen utgår fra en blodprøve, vil den kunne være til stor nytte i de deler av verden der man ikke har tilgang til mammografi (2). Lund får 1,3 millioner kroner (150 000 euro) for en periode på ett år for å undersøke mulighetene for å kommersialisere blodprøvemetoden han har utviklet på grunnlag av egen tidligere ERC-støttede genforskning.

ERCs «proof of concept» tildeles kun forskere som allerede har mottatt tilskudd fra organisasjonen. Disse kan søke om tilleggsfinansiering for å utvikle innovasjonspotensialet til en idé fra sitt ERC-prosjekt. I 2008 fikk Lund 20 millioner kroner for fem år til finansiering av sitt grunnforskningsprosjekt.

Det europeiske forskningsrådet ble etablert i 2007 som en del av EUs sjuende rammeprogram for forskning (FP7). De skal støtte grensesprengende forskning. Stipendene gis til enkeltforskere og har høy prestisje. Gjennom EØS-avtalen deltar Norge i EUs rammeprogram for forskning og innovasjon i regi av det europeiske forskningsrådet.

\section{Gunn Marit Seberg}

gunn.marit.seberg@legeforeningen.no

\section{Litteratur}

1. Skuland B. Norsk kreftforsker får ERC-støtte til kommersialisering. Forskningsrådet. www.forskningsradet.no/prognett-horisont2020/Nyheter/ Norsk kreftforsker fr ERCsttte til kommersialisering/1254006531935/ p1253988679434 (18.3.3.2015).

2. Øvreberg E. Har klart det umulige - igjen! http://uit.no/nyheter/artikkel?p_document id=404054 (18.3.2015). 